\title{
IDENTIFIKASI KECERDASAN LOGIS MATEMATIS SISWA KELAS IX SMPN 12 KOTA TARAKAN
}

\section{IDENTIFICATION OF LOGICAL MATHEMATICAL INTELLIGENCE STUDENTS OF CLASS IX SMPN 12 TARAKAN}

\author{
Setia Widya Rahayu ${ }^{1)}$, Tri Junarto ${ }^{2)}$ \\ ${ }^{1)}$ Fakultas Keguruan dan Ilmu Pendidikan, Universitas Borneo Tarakan \\ 2) SMPN 12 Tarakan \\ Email: ${ }^{1}$ Setia.widiaayu@borneo.ac.id, ${ }^{2}$ trijunartosmpn12tarakan@gmail.com
}

\begin{abstract}
ABSTRAK
Dalam pembelajaran matematika didukung oleh 2 faktor, yaitu faktor eksternal dan faktor internal. Salah satu faktor internal yang mendukung siswa dalam mempelajari matematika adalah kecerdasan logis matematis. Oleh karena itu peneliti tertarik untuk melakukan penelitian pada siswa kelas IX SMPN 12 Tarakan. Adapun tujuan penelitian ini untuk mengidentifikasi kecerdasan logis matematis siswa kelas IX SMPN 12 Kota Tarakan. Metode penelitian yang dilakukan dengan menggunakan pendekatan kuantitatif deskriptif. Berdasarkan hasil penelitian yang telah dilaksanakan diperoleh kecerdasan logis matematis siswa kelas IX SMPN 12 Tarakan berada pada kategori Tinggi sebesar 10\%, Sedang 30\% dan Rendah 60\%. Siswa dengan kategori kecerdasan logis matematis tinggi mampu membuat klasifikasi tentang informasi-informasi, membadingkan informasi dan strategi untuk memecahkan masalah dengan tepat, mengolah bilangan-bilangan dan menggunakan pemikiran induktif maupun deduktif. Siswa dengan kategori kecerdasan logis matematis sedang, mmpu mengklasifikasi informasi-informasi, membandingkan informasi dan strategi untuk memecahkan masalah dengan tepat, tetapi masih kurang tepat dalam mengolah bilangan-bilangan dan mengungkapkan pemikiran induktif dan deduktif. Sedangkan siswa dengan kecerdasan logis matematis kategori rendah, kurang mampu untuk membuat klasifikasi tentang informasi-informasi, membadingkan informasi dan strategi untuk memecahkan masalah dengan tepat, mengolah bilanganbilangan dan menggunakan pemikiran induktif maupun deduktif.
\end{abstract}

Kata Kunci : Identifikasi, Kecerdasan Logis Matematis

\begin{abstract}
Mathematics learning is supported by 2 factors, external factors and internal factors. One of the internal factors that support students in learning mathematics is mathematical logical intelligence. The research are interested in conducting research on class IX students of SMP 12 Tarakan. The purpose of this study is to identify mathematical logical intelligence of class IX students of SMP 12 Kota Tarakan. The research method using a descriptive quantitative. Based on the results of the research that has been carried out obtained mathematical logical intelligence class IX students of 12 Tarakan Junior High School are in the High category of 10\%, Medium 30\% and Low 60\%. Students with a high mathematical logical intelligence category are able to classify information, compare information and strategies to solve problems correctly, process numbers and use inductive and deductive thinking. Students with the category of moderate mathematical intelligence are able to classify information, compare information and strategies to solve problems correctly, but are still less precise in processing numbers and expressing inductive and deductive thinking. While students with mathematical logical intelligence in the low category, are less able to classify information, compare information and strategies to solve problems correctly, process numbers and use inductive and deductive thinking.
\end{abstract}

Keywords: Identification, Mathematical Logical Intelligence 


\section{PENDAHULUAN}

Matematika adalah salah satu pelajaran yang dipelajari dari Sekolah Dasar hingga Perguruan Tinggi. peran matematika. Penguasaan terhadap pelajaran matematika memberikan manfaat yang sangat besar bagi kehidupan. Karena dikehidupan sehari-hari selalu berkaitan dengan matematika. Matematika yang dipelajari siswa disekolah diajarkan oleh guru yang memang memiliki latar belakang pendidikan matematika.

Para pendidik matematika umumnya menyadari bahwa matematika bukanlah termasuk bidang studi yang mudah bagi kebanyakan siswa. Para pendidik matematika baik di sekolah dasar maupun di sekolah menengah, umumnya tahu bahwa banyak konsep, prinsip, dan fakta dalam matematika sukar dikuasai oleh siswa. Kondisi tersebut menyebabkan sebagian siswa menganggap matematika adalah mata pelajaran yang sulit dan tidak menarik, walaupun fakta yang ditemukan dilapangan masih ada beberapa siswa yang lebih menyukai pelajaran matematika dibandingkan dengan pelajaran lainnya. Dari hasil wawancara peneliti kepada salah satu guru matematika disekolah diperoleh fakta bahwa siswa di SMPN 12 kurang minat dengan pelajaran matematika, ketika jam pelajaran matematika dikelas siswa kurang antusias dan aktif, selain itu siswa cenderung memilih diam ketika biberi pertanyaan dari gurunya.

Sedangkan hasil wawancara peneliti ke beberapa siswa, diperoleh fakta bahwa pelajaran matematika dianggap sulit karena berhubungan dengan angka-angka dan rumus, akan tetapi ada materi-materi tertentu yang disukai siswa dalam pelajaran matematika. Kondisi tersebut dapat dilihat dari hasil belajar matematika siswa yang masih dibawah KKM. Walaupun hasil belajar itu meliputi dua faktor yaitu faktor internal dan eksternal. Faktor internal mencakup faktor fisiologis dan psikologis, misalnya: kecerdasan, motivasi berprestasi, dan kemampuan kognitif. Faktor eksternal mencakup faktor lingkungan dan instrumental seperti: guru, kurikulum dan metode pembelajaran. Dari beberapa faktor tersebut, kecerdasan hanya merupakan salah satu faktor yang ikut menentukan atau mempengaruhi keberhasilan dalam belajar. Menurut Gardner (2003), kecerdasan merupakan kemampuan untuk menangkap situasi baru serta kemampuan untuk belajar dari pengalaman masa lalu seseorang. Kecerdasan bergantung pada konteks, tugas serta tuntutan yang diajukan oleh kehidupan kita, dan bukan tergantung pada nila IQ, gelar perguruan tinggi atau reputasi bergengsi. Salah satu jenis kecerdasan yang memiliki bagian besar dalam proses pembelajaran matematika adalah kecerdasan logis matematis. Siswa yang dominan kecerdasan logis matematisnya secara menonjol dapat memikirkan sistem-sistem yang abstrak, seperti matematika dan filsafat. Orang yang mempunyai kecerdasan ini, mudah belajar menghitung, bermain dengan angka. Bahkan, ia dengan senang menggeluti simbol angka dalam buku matematika daripada kalimat panjangpanjang. Pemikiran orang seperti ini adalah ilmiah dan berurutan. Berdasarkan dari faktafakta yang diperoleh, maka peneliti tertarik untuk melakukan penelitian berjudul "Profil Kemampuan Logis Matematis Siswa SMPN 12 Tarakan".

\section{METODE PENELITIAN}

Berdasarkan dari analisis dan jenis data yang digunakan, maka dalam penelitian ini peneliti menggunakan pendekatan kuantitatif karena jenis data yang akan dianalisis adalah data yang berupa angka. Adapun di penelitian ini peneliti tidak mengadakan perlakuan secara langsung kepada siswa tetapi memberikan tes dalam bentuk multiple choice untuk mengetahui kemampuan logis matematis siswa. Penelitian ini dilaksanakan pada semester genap tahun ajaran 2018/2019 pada bulan Januari 2019. Lokasi penelitian ini, yaitu SMPN 12 Tarakan, kelurahan Karang Anyar Pantai, Kecamatan Tarakan Barat.

Populasi dalam penelitian ini adalah seluruh siswa kelas IX SMPN 12 Tarakan yang jumlah siswanya 200 orang. Sampel dalam penelitian ini berjumlah 120 orang. Teknik pengambilan sampel menggunakan rumus Teknik 
pengambilan sampel pada penelitian ini menggunakan teknik sample random sampling (sampel acak sederhana). Hal ini dikarenakan pembagian kelas di SMPN 12 Tarakan dilakukan secara heterogen, sehingga semua kelas mendapatkan kesempatan yang sama untuk menjadi sampel penelitian.

Tes digunakan untuk mengumpulkan data kuantitatif serta untuk mengetahui kecerdasan logis matematis kelas IX. Tes diberikan kepada seluruh siswa di kelas IX SMPN 12 Tarakan. Testnya berupa soal multiple choice. Soal yang diberikan sesuai dengan indikator kecerdasan logis matematis. Instrumen akan di uji coba terlebih dahulu. Uji coba instrumen ini bertujuan untuk mengetahui kelayakan suatu instrumen.

\section{Keterangan:}

$$
\bar{X}=\frac{\sum x i}{n}
$$

$X \quad=$ Rata-rata (mean)

$\Sigma=$ Jumlah nilai $x$ pertama sampai ke- $n$ $=$ Jumlah individu

Simpangan baku dengan simbol (s) dirumuskan seperti rumus berikut (Supardi, 2013:79):

\section{Keterangan:}

$$
s=\sqrt{\frac{\sum(X i-\bar{X})^{2}}{(n-1)}}
$$

$s \quad=$ Simpangan baku sampel

$X i-X=$ Jarak antara nilai individu dengan rata-rata (simpangan)

$n-1=$ Derajat Kebebasan

Setelah diketahui nilai rata-rata (mean) dan simpangan baku variabel serta hasil tes tingkat kecerdasan logis matematis dan angket minat
Dalam penelitian ini, peneliti menggunakan validitas kuantitatif. Setelah dilakukan validitas isi terhadap instrumen, instrumen akan diujicobakan untuk menguji validitas butirinstrumen lebih lanjut. Hasil tes akan diurutkan dari nilai tertinggi sampai nilai terendah. Analisis item ini meliputi daya pembeda, tingkat kesukaran, fungsi distraktor, validitas butir soal dan pengujian reliabilitas.

Selanjutnya untuk nilai Rata-rata (mean) ini didapat dengan menjumlahkan data seluruh individu dalam kelompok itu, kemudian dibagi dengan jumlah individu yang ada pada kelompok tersebut. Hal ini dapat dirumuskan seperti rumus berikut (Sugiyono, 2013:49):

Tabel 1. Kategori Kecerdasan Logis Matematis Siswa

\begin{tabular}{|c|c|c|}
\hline No & Interval & Kategori \\
\hline 1 & $M_{i}+1,5 S b i<x$ & Tinggi \\
2 & $M_{i}+0,5 S b i<x \leq M_{i}+1,5 S b i$ & Sedang \\
3 & $x \leq M_{i}+0,5 S b i$ & Rendah \\
\hline
\end{tabular}

Sumber: Modifikasi dari Azwar (2015:163)

belajar dari responden, maka setiap variabel dikategori tingkat kecerdasan logis matematis sebagai berikut:

\section{Keterangan:}

Mean Ideal (Mi)

$: 1 / 2$ (skor tertinggi + skor terendah)

Simpangan baku ideal (Sbi) : 1/6 (skor tertinggi - skor terendah)

$x$

skor tertinggi ideal

skor terendah ideal

: skor yang diperoleh

: skor tertinggi tiap pernyataan

: skor terendah tiap pernyataan 
Penilaian keterampilan kemampuan berhitung dianalisis dengan mengguanakan penskoran kemampuan berhitung sehingga perhitungan nilai mean ideal dan simpangan baku ideal adalah sebagai berikut:

$$
\begin{aligned}
\text { Mi } & =1 / 2(\text { skor tertinggi }+ \text { skor terendah }) \\
& =1 / 2(100+0) \\
& =1 / 2(100) \\
& =50
\end{aligned}
$$

$$
\begin{aligned}
\text { Sbi } & =1 / 6(\text { skor tertinggi }- \text { skor terendah }) \\
& =1 / 6(100-0) \\
& =16,6
\end{aligned}
$$

Berdasarkan penentuan mean ideal (Mi) dan simpangan (Sbi) dapat ditentukan interval

kategori penilaian kemampuan berhitung matematika siswa.

Tabel 2. Kategori kemampuan berhitung Matematika Siswa

Sumber: Modifikasi dari Azwar (2015:163)

\begin{tabular}{ccc}
\hline No & Interval & Kategori \\
\hline 1 & $75<x$ & Tinggi \\
2 & $58<x \leq 75$ & Sedang \\
3 & $x \leq 58$ & Rendah \\
\hline $2015: 163)$ & &
\end{tabular}

Selain penilaiaan keterampilan kemampuan jumlah siswa per skema pada setiap item soal. berhitung peneliti menghitung juga persentase

Dengan menggunakan rumus sebagai berikut:

$$
\text { persentase jumlah siswa perskema }=\frac{\text { jumlah siswa per skema }}{\text { jumlah seluruh siswa }}
$$

\section{HASIL DAN PEMBAHASAN}

Berdasarkan pengumpulan data penelitian Kelompok Kategori Kecerdasan Logis Matematis

Siswa yang telah dilakukan di SMPN 12 Tarakan diperoleh hasil sebagai berikut:

Tabel 3. Kelompok Kategori Kecerdasan Logis Matematis Siswa

\begin{tabular}{|c|c|c|c|c|}
\hline No & Interval & Kategori & Jumlah Siswa & Persentase \\
\hline 1 & $75<x$ & Tinggi & 12 & $10 \%$ \\
2 & $58<x \leq 75$ & Sedang & 36 & $30 \%$ \\
3 & $x \leq 58$ & Rendah & 72 & $60 \%$ \\
\hline & Jumlah & & 120 & $100 \%$ \\
\hline
\end{tabular}

Berdasarkan tabel kategori kecerdasan logis matematis, siswa berada pada kategori tinggi sebesar $10 \%$, sedang $30 \%$ dan rendah $60 \%$. Dari keseluruhan sampel yang diteliti yaitu 120 siswa, sebanyak 10 siswa memiliki nilai diatas 75 , dan sebanyak 36 siswa memiliki nilai diatas 58 , serta 72 siswa memiliki nilai dibawah 58.

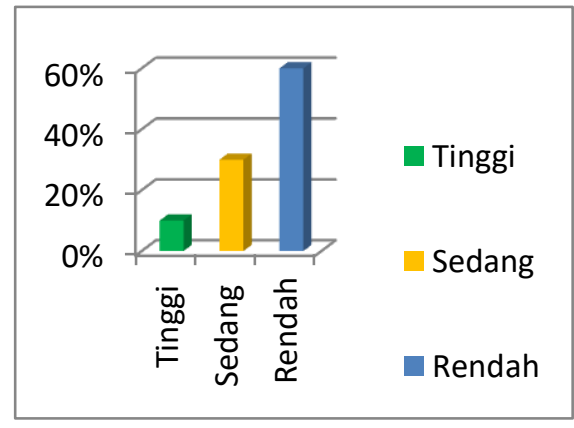

Gambar 1. Diagram Persentase Kecerdasan Logis Matematis Siswa 


\section{KESIMPULAN}

Berdasarkan hasil penelitian yang dikemukakan oleh peneliti, maka dapat disimpulkan kecerdasan logis matematis siswa kelas IX SMPN 12 Tarakan berada pada kategori Tinggi sebesar 10\%, Sedang 30\% dan Rendah 60\%. Siswa dengan kategori kecerdasan logis matematis tinggi mampu membuat klasifikasi tentang informasi-informasi, membadingkan informasi dan strategi untuk memecahkan masalah dengan tepat, mengolah bilanganbilangan dan menggunakan pemikiran induktif maupun deduktif. Siswa dengan kategori kecerdasan logis matematis sedang, mampu mengklasifikasi informasi, membandingkan informasi dan strategi untuk memecahkan masalah dengan tepat, tetapi masih kurang tepat dalam mengolah bilangan dan mengungkapkan pemikiran induktif dan deduktif.

Sedangkan siswa dengan kecerdasan logis matematis kategori rendah, kurang mampu untuk membuat klasifikasi tentang informasiinformasi, dan tidak dapat membadingkan informasi dan strategi untuk memecahkan masalah dengan tepat, mengolah bilanganbilangan dan menggunakan pemikiran induktif maupun pemikiran deduktif.

\section{DAFTAR PUSTAKA}

Arikunto, Suharsimi. 2013. Dasar-dasar Evaluasi Pendidikan Edisi 2. Jakarta: Bumi Aksara.

Azwar, S. (2015). Penyusunan Skala Psikologi Edisi 2. Yogyakarta: Pustaka Belajar.

Gardner, Howard. 2003. Kecerdasan Majemuk. (Terjemahan Drs. Alexander Sindoro). Batam Centre: Interaksara.

Sugiyono. ,2007. Memahami Penelitian Kualitatif, Bandung: Alfabeta.

Supardi. (2013) Aplikasi Statistika dalam Penelitian Konsep Statistika yang Lebih Komprehensif. Jakarta: Change Publication. 
